\title{
Ekphrasis and the feminine in Sannazaro's Arcadia
}

Melinda A. Cro

\section{How to cite this manuscript}

If you make reference to this version of the manuscript, use the following information:

Cro, M. A. (2012). Ekphrasis and the feminine in Sannazaro's Arcadia. Retrieved from http://krex.ksu.edu

\section{Published Version Information}

Citation: Cro, M. A. (2012). Ekphrasis and the feminine in Sannazaro's Arcadia. Romance Notes, 52(1), 71-78.

Digital Object Identifier (DOI): doi:10.1353/rmc.2012.0005

Publisher's Link:

http://muse.jhu.edu/login?auth=0\&type=summary\&url=/journals/romance_notes/v052/52 .1.cro.html 


\title{
EKPHRASIS AND THE FEMININE IN \\ SANNAZARO'S ARCADIA
}

\author{
Melinda A. CRO

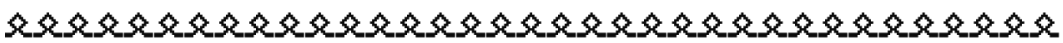

IN Chapter III of Jacopo Sannazaro's Arcadia (1504), the shepherds celebrate the feast of Pales, "veneranda dea di pastori." As the shepherds enter the temple, the narrator describes the murals on the walls, struck by a depiction of nymphs laughing at a little ram. While distracted by nature's tableau, a group of satyrs steals upon the nymphs and, realizing the peril they face, the nymphs take flight. The mural comes to life as the author describes the nymphs' rapid and panicked escape from the threat of physical violence as the satyrs give chase. This particular mural is one of a series of tableaux found on the walls in Pales' temple. The group of murals could be considered an example of collectionist ekphrases, a term described by Frederick A. de Armas as a set of descriptions of works of art that can be grouped together and thus constitute a museum or gallery within a text and whose purpose is to "foreground a major topic or question posited by the text" (23). The first of the tableaux painted above the doorway is a typical, humble pastoral scene of a verdant, lush meadow inhabited by dogs and shepherds with their flocks, some tending to the livestock, some playing the pipes. The next scene described is that of the nymphs to which the author draws the reader's attention by underlining the pleasure it affords the narrator upon viewing it. This tableau is followed by a depiction of Apollo guarding Admetus' herds and Mercury stealing one of the cows. This instance of ekphrasis stands out from what has preceded structurally in the novel - descriptions of shepherds, their loves, their singing competitions, the landscape of Arcadia itself; and poetic dialogues or monologues by the shepherds on similar themes. This departure from form leads the reader to consider the purpose for 
the inclusion of this set of ekphrases and the motive behind the description of a scene as rife with menacing undertones as that of the flight of the nymphs. I propose that the ekphrasis serves a dual purpose, extending beyond the decorative. The mural personifies what Renato Poggioli might term the "normal erotic impulses" (61) inherent within pastoral where woman is identified as an object to be conquered and possessed. Further, the tableau foreshadows a second instance of ekphrasis later in the text that goes to the core of the genesis of the pastoral mode as conceived by Sannazaro.

Pastoral happiness, for Poggioli, is defined in terms of fulfillment the "fulfillment of the passion of love, the consummation of the man's erotic wishes" (42), lending a strikingly sexual element to the pastoral conception of love and aligning the notion of happiness with that of "erotic hedonism" (49). The pastoral relationship is conceived as occurring between a young female - a nymph or a shepherdess - and a male of any age. While the beauty of the woman hinges upon her youth, her springtime essence, her partner's age is of little consequence because pastoral, in particular Renaissance Italian pastoral, is not only a mode of retreat from society - it is man's retreat from society. The pastoral experience is often viewed from the man's perspective rather than the woman's, and thus the whole world is interpreted through what Poggioli considers to be a patriarchal lens although phallocentric lens might be a more accurate term given the emphasis on the sexual.

Relying primarily on Tasso's Aminta (1573) as source, Poggioli argues that in pastoral it is the law of nature that reigns rather than the law of society. The law of nature champions free love (always from a phallocentric perspective that does not consider rejection on the part of the female to be acceptable) as opposed to the law of society that restricts the passion of love, dictating its proper expression which is in direct opposition to what Freud would label as natural erotic desires. Pastoral functions as a retreat from social convention where the male author and/or reader may take the liberty to act upon his erotic impulses and then persuade himself that such an action is permitted because it follows the "law of nature."

Male satisfaction is central to the treatment of ekphrasis in Chapter III. Sincero, the narrator, finds pleasure in viewing the painting of the nymphs and the satyrs, indicating that the reader, too, by extension, should delight in this description: 
Ma quel che piú intentamente mi piacque di mirare erano certe ninfe ignude, le quali dietro un tronco di castagno stavano quasi mezze nascose, ridendo di un montone che per intendere a rodere una ghirlanda di quercia che dinanzi agli occhi gli pendea, non si ricordava di pascere le erbe che dintorno gli stavano. (76)

The emphasis on the visual nature of the appreciation is clear through the lexical choices the author makes - "mirare" and "agli occhi" both refer to the eyes, the act of seeing, signaling the reader that this is an instance of ekphrasis and must be appreciated in terms of the visual as well as the written. However, the reason for the narrator's enjoyment is not made explicitly clear to the reader. One is not sure if he is pleased with the overall composition and the care with which the painter prepared the tableau; the nymphs' presence and their capacity to escape the threat of the satyrs; or the chase of the nymphs which he might find exhilarating.

The tableau comes to life as the narrator/reader views/reads it - the nymphs laugh at the little distracted ram then flee as the satyrs chase after them:

In questo venivano quattro satiri con le corna in testa e i piedi caprini, per una macchia di lentischi pian piano, per prenderle dopo le spalle; di che elle avedendosi, si mettevano in fuga per lo folto bosco, non schivando né pruni né cosa che gli potesse nocere. De le quali una, piú che le altre presta, era poggiata sovra un càrpino, e quindi con un ramo lungo in mano si difendea; le altre si erano per paura gittate dentro un fiume, e per quello fuggivano notando, le chiare onde poco o niente gli nascondevano de le bianche carni. (76-7)

Keeping Poggioli's theory in mind, the inclusion of this ekphrasic description might be an example of the narrator taking pleasure in the freedom to act upon one's desires when inspired by love (or lust, as is more appropriate for this depiction). Yet the narrator has expressed no such interest in erotic fancy prior to this moment, leaving the reader to question the function of this scene. If its inclusion is limited to a representation of male lust liberated from the shackles of social convention and so following the law of nature, then the failure of the satyrs to triumph here seems problematic. While rape might not be discussed out of regard for propriety (although neither Boccaccio in the Ninfale fiesolano nor Tasso in the Aminta hesitates to describe similar moments), in this scene the satyrs do not even manage to catch the nymphs. In fact, the nymphs chastise the satyrs from their perch on the opposite bank, undercutting the tension the chase introduced into the idyllic world: 
Ma poi che si vedevano campate dal pericolo, stavano assise da l'altra riva affannate e anelanti, asciugandosi i bagnati capelli; e quindi con gesti e con parole pareva che increpare volessono coloro che giungere non le avevano potuto. (77)

Certainly, the choice of topic for representation is commonplace within the pastoral (indeed, even in Roman and Greek mythology) and there is little doubt that subconscious male desires find expression in this scene. However, one cannot limit the interpretation of this scene to merely the expression of pastoral eroticism, especially considering the wealth of literary allusion and intertextuality that Sannazaro invests in each episode of his pastoral work. There is a palpable danger in this instance of ekphrasis. The threat posed by the satyrs is made plain through the author's lexical decisions - the nymphs fling themselves into the river out of fear ("per paura"); one has to defend herself with a branch ("si difendea"); they realize on the bank that they have escaped from the danger ("dal pericolo"). The threat of violence is real in this mural and the pastoral setting undergoes a shocking transformation - in the space of a few lines the peaceful, bucolic landscape becomes a terrifying place for the woman to inhabit, one which she must flee as soon as possible. Then, just as suddenly, peace returns to Arcadia, as though it had never left. This passage sends a clear message to the reader: the threat of violence is ever-present in Arcadia, and this threat is expressed in terms of the masculine domination of the feminine.

The complexity of meaning in this instance of ekphrasis is further deepened because of the referential nature of the work itself. Sannazaro writes for an erudite reader, relying on the reader's ability to recognize and understand the rich tapestry of literary allusion he weaves. In this section of ekphrasis alone, Erspamer traces references to Boccaccio's Decameron, Ovid's Metamorphoses, and Virgil's Aeneid (76-7). Indeed, while Erspamer does not mention it, I believe that we can find the literary precedent for the temple paintings in the Aeneid in Book I, as Aeneas enters Dido's temple to Juno and observes the paintings depicting the Trojan War (vv. 547-599). Granted, Sannazaro's passage is not a scene of battle and Sincero, the narrator, is not moved to tears at the sight of the paintings. What we can observe, however, is the transposition of the technique and a similarity in the composition. Both temples serve a female goddess, linking the paintings therein and their creation with the feminine. Thus, artistic creation is aligned with the woman, 
conceived as goddess, at once eternally youthful and beautiful and completely unattainable. In each text there is a strong emotional reaction to the paintings from the protagonist that calls the reader's attention to the passage. Further, both authors have prepared a narrative ekphrasis that borders on the dramatic. Sannazaro has altered the elements to conform to the more "humble" mode of pastoral rather than epic, but the technique is most certainly similar. The author invites the reader to discover the reason behind the inclusion of each element and each allusion. The key to that answer lies in the nature of the ekphrastic segments.

James Heffernan asserts that ekphrasis is "the verbal representation of the graphic representation" (299) and that what ekphrasis describes must be representational, must have been created for the purposes of representing something (300). De Armas also indicates that the inclusion of collectionist ekphrasis points to the central themes of a text. Given this emphasis on representation, it is then up to the reader to decide what Sannazaro intended the tableau of the nymphs to represent. I posit that the painting is a pastoral mise-en-abyme that echoes the story of Pan and Syrinx introduced in Chapter X through the representation of the sampogna and goes to the heart of the genesis of the pastoral mode, inciting the reader to observe the parallel use of ekphrasis in order further to elucidate the nature of Arcadia.

In Chapter X, the group of shepherds has left the pastoral fields and entered a sacred wood. Therein, in a clearing in the pine trees, they find a cave that houses a statue of Pan upon a stone altar fashioned by the shepherds: "sovra al quale si vedeva di legno la grande effigie del selvatico idio" (166). Sannazaro describes the materials used, further underlining the verisimilitude of the representation. On either side of the altar hang the laws and rules governing conduct for pastoral life, the pastoral "commandments," and in front of the cave, hanging from a pine tree is the sampogna, Pan's flute made of seven reeds. Again, Sannazaro describes how the item is fashioned, echoing Homer's description of Achilles' shield and emphasis on how it was forged. The shepherds ask the priest leading the pilgrimage to Pan's cave who wrought this flute since clearly "da divine mani composta e incerata" (168) and the "savio sacerdote" explains that the reeds were once the beautiful nymph Syrinx whom Pan loved. She rejected his love, a rejection he did not accept. While he chased her she came to a river and, unable to cross, pleaded with the river nymphs to be saved 
from his advances. She was transformed into a reed and Pan, in his great love for her, cut her and made her into his instrument. The material comes from Ovid's Metamorphoses and when Pan plays his pipes he asserts that it is Syrinx, too, who sings: "This sylvan pipe will enable us always to talk together!'” (I:710). Pan, the satyr god of pastures and shepherds, notorious for his sexuality (often depicted pictorially with an immense phallus) chased the nymph, Syrinx, chaste follower of Artemis who, so desperate was she to escape that she prayed for intervention, a prayer answered by the river nymphs who transformed her into a reed. They will forever sing in unison. The painting in Pales' temple foreshadows this very scene evoked by the ekphrasis of the sampogna outside Pan's cave.

Continuing his story of the sampogna, the priest tells of the great masters who have played the grand pastoral flute after Pan - he alludes to Theocritus, whose Idylls are recognized by critics as the genesis of the pastoral mode; and Virgil, whose Eclogues were immensely influential. Thus, Sannazaro provides a literary genealogy for pastoral through the "players" of the sampogna, implicitly including himself in the lineage given that the mythical sampogna has now found its way into his pastoral work and his alone. The flight of the nymphs in Chapter III foreshadows the description of the flight of Syrinx in Chapter X and leads the reader at once to the moment of the birth and rebirth of pastoral - Pan's creation of the sampogna, the shepherd's instrument that sings of the simple pastoral existence; and Sannazaro's renewal of pastoral in the vernacular through Arcadia. Divine inspiration, as at the temple of Pales, plays a role in the generation of the art object that then becomes the center of the ekphrasis and of the pastoral.

The mythical advent of pastoral as conceived by Sannazaro, however, carries with it a darker reality than is at first understood. On the surface, it seems as though it were an honor for Syrinx, as reed, to become the noble instrument of the pastoral mode. She is forever immortalized by the gods. Like them, she is in her new form eternally youthful and, on the surface, unattainable by Pan. However, the modern reader must consider the ramifications of the myth as Sannazaro tells it. Syrinx did not truly escape her tormentor. She was still violated by the god - he molded her to fit his purposes and, after her transformation, she no longer had a will with which to fight him. If we 
understand rape to be the violation of the woman's wishes and her subjugation to the male's desires, then pastoral literature is "born" from this forced union between Pan and Syrinx. This foundation narrative recalls the genesis of a mode propelled into creation by the masculine imposition onto the feminine. The act of plucking the reed and fashioning the flute is pregnant with sexual undertones and results in the birth of pastoral. Pastoral literature is the result of a rape, albeit explained in overwhelmingly positive terms by the author who, while almost certainly aware of the implications, does not seem to perceive it as problematic. Hence the erotic is linked with the mode from its inception wherein the feigned innocence of the shepherd-visitor permits the ignorance of the laws of society and the support of the law of nature where brute strength and masculine desire determine the outcome. The genteel pastoral landscape of the temple mural gives way to a desperate flight of nymphs. In this land of idyllic love and bucolic fancy, the phallic not only undermines the peace, it is at the core of the genesis of the mode. The menace of violence is always brewing just below the surface in Arcadia, where man retreats temporarily in order to escape the constraints imposed upon him by society.

Sannazaro's use of ekphrasis informs not only the reader's understanding of the setting but the entirety of the pastoral mode. Arcadia is a world where the physical and visual are highly valued. This emphasis on the visual and physical within the phallocentric pastoral universe, however, leads to violence, a violence accepted by the author as inevitable and the fruit of which must be considered in a positive light because it is at the advent of the mode itself. The seemingly peaceful, idyllic way of life that is described in such vivid, pictorial terms is wrought with often invisible dangers that at once threaten and reaffirm the mode's existence. The ever-present threat of violence recalls the inception of the mode itself, an inception that Sannazaro renders clear through the careful use of ekphrasis. 


\section{Works CITED}

Armas, Frederick A. de. "Simple Magic: Ekphrasis from Antiquity to the Age of Cervantes." Ekphrasis in the Age of Cervantes. Lewisburg: Bucknell UP, 2005. 13-31.

Brown, David Alan, et al. Bellini, Giorgione, Titian, and the Renaissance of Venetian Painting. New Haven: Yale UP, 2006.

Heffernan, James A. W. "Ekphrasis and Representation." New Literary History 22:2 (Spring 1991): 297-316.

Ovid. Metamorphosis. Trans. David Raeburn. New York: Penguin, 2004.

Panofsky, Erwin. Meaning in the Visual Arts: Papers in and on Art History. Garden City, NY: Doubleday Anchor Books, 1955.

Poggioli, Renato. The Oaten Flute: Essays on Pastoral Poetry and the Pastoral Ideal. Cambridge: Harvard UP, 1975.

Sannazaro, Jacopo. Arcadia. Ed. Francesco Erspamer. Milan: Gruppo Ugo Mursia Editore, 1990. 
Copyright of Romance Notes is the property of University of North Carolina, Department of Romance Languages and its content may not be copied or emailed to multiple sites or posted to a listserv without the copyright holder's express written permission. However, users may print, download, or email articles for individual use. 